\title{
Effects of early tidal inundation on the cycling of methylamines in inter-tidal sediments
}

\author{
M. F. Fitzsimons ${ }^{1, *}$, M. Dawit ${ }^{2}$, D. M. Revitt ${ }^{2}$, C. Rocha $^{3}$ \\ ${ }^{1}$ Petroleum and Environmental Geochemistry Group, School of Earth Ocean and Environmental Science, \\ University of Plymouth, Drake Circus, Plymouth PL4 8AA, UK \\ ${ }^{2}$ Urban Pollution Research Centre, Middlesex University, Queensway, Enfield, Middlesex EN3 4SA, UK \\ ${ }^{3}$ Center for Marine and Environmental Research (CIMA), Universidade do Algarve, FCMA, Campus de Gambelas, \\ 8000-810 Faro, Portugal
}

\begin{abstract}
Methylamine (MA) concentrations were measured at 2 sites in the Ria Formosa, Portugal, including a rearing plot for the clam Ruditapes decussatus (L). Sampling encompassed both sediment exposure and tidal inundation. Porewater MA concentrations at Site 1 (cohesive sediment with low numbers of clams) did not change significantly during sediment exposure, but increased at the onset of inundation, with desorption of solid-phase monomethylamine (MMA) mainly responsible. Porewater dimethylamine (DMA) did not vary significantly, while porewater trimethylamine (TMA) concentrations decreased after inundation. Solid-phase MA concentrations at Site 1 were more variable, where TMA was consumed at a rate of $60 \mu \mathrm{mol} \mathrm{kg}{ }^{-1}$ bulk sediment $\mathrm{h}^{-1}$ during the first hour of sampling, suggesting that it was loosely bound to the sediment. The consumption of solid-phase TMA at Site 1 may contradict the notion of adsorption as a preservation mechanism for certain basic analytes. MA concentrations were considerably higher in the sediment and clam samples from Site 2, containing high densities of $R$. decussatus, where TMA was the most abundant MA. Its concentrations in clam tissue before inundation were 191 decreasing to $36 \mathrm{mmol} \mathrm{kg}{ }^{-1}$ after inundation. A concurrent increase in sediment solid-phase TMA from 0.1 to $0.9 \mathrm{mmol} \mathrm{kg}{ }^{-1}$ pointed to release of TMA by the clams. Excretion of TMA from the clam tissue should have increased the sediment concentration by $2.19 \mathrm{mmol} \mathrm{kg}^{-1}$, but the measured value was $0.84 \mathrm{mmol} \mathrm{kg}{ }^{-1}$. The low adsorption capacity of sandy sediment and the fact that clams excrete their waste close to the sediment surface should increase the possibility of TMA flushing to the water column. The high density of clams, and the current preference for clam rearing in sandy sediments, could contribute to increased concentrations of dissolved nitrogen in the Ria Formosa lagoon.
\end{abstract}

KEY WORDS: Monomethylamine $\cdot$ Dimethylamine $\cdot$ Trimethylamine $\cdot$ Ruditapes decussatus $\cdot$ Ria Formosa $\cdot$ Tidal inundation $\cdot$ Solid-phase $\cdot$ Porewater

Resale or republication not permitted without written consent of the publisher

\section{INTRODUCTION}

Inter-tidal areas are dynamic ecosystems where large amounts of organic matter undergo rapid decomposition, producing $\mathrm{NH}_{4}{ }^{+}$as a by-product of organic nitrogen mineralization (Boulegue et al. 1982). When sediment is not physically or biologically perturbed, porewater profiles reflect chemical zonation resulting from post-depositional transformations (Aller 1994). However, regular covering and uncovering of sediment by the tide induces a non-equilibrium condition (e.g. Harvey \& Odum 1990, Kerner \& Wallman 1992, Rocha 1998, Rocha \& Cabral 1998). During exposure, the sediment is subject to different conditions of light, temperature and pressure, while inundation introduces oxygen and increases porewater salinity through mixing between overlying water and porewater. Sediment resuspension promotes changes in the sorption equilibrium of species such as $\mathrm{NH}_{4}{ }^{+}$(Simon 1989, Morin \& Morse 1999), while percolation of oxygenated seawater into suboxic sediment causes a 
change from anoxic to oxic mineralization (Kerner \& Wallman 1992). Tidal cycling, thus, causes alterations in the existing equilibrium between porewater and sediment solids. During the first minutes of tidal inundation, porewater and sediment-desorbed compounds are injected into the overlying water and sediment may also be resuspended. Benthic organisms influence sediment chemistry through bioturbation of the sediments by both deposit and filter-feeding invertebrates (Raffaelli \& Hawkins 1999), or by direct release of chemical species into the sediments (e.g. Sørensen \& Glob 1987, Wang \& Lee 1994).

The methylamines (MAs) are chemical analogues of ammonia, containing 1 (monomethylamine, MMA), 2 (dimethylamine, DMA) or 3 (trimethylamine, TMA) methyl groups. They are now known to be ubiquitous in marine systems at concentrations ranging from nanomolar in the open ocean (Gibb et al. 1999) to micromolar in estuarine sediments (Sørensen \& Glob 1987, Wang \& Lee 1990, 1994, Fitzsimons et al. 1997, 2001). However, their cycling in the marine environment and their role within organisms is still a matter of speculation. In inter-tidal sediments, osmoregulation by benthic invertebrates has been proposed as a source of TMA (Sørensen \& Glob 1987), while the seasonal senescence of salt marsh plants demonstrably enhances MA concentrations in sediments (Wang \& Lee 1994). MAs may also be produced through the degradation of trimethylamine oxide (TMAO), which is present at high concentrations in marine animals (Seibel \& Walsh 2002). MAs can be degraded under both aerobic and anaerobic conditions, and have been implicated in the production of methane in salt marsh sediments (Franklin et al. 1988, Oremland et al. 1982), allowing methanogens to co-exist with sulphatereducing bacteria. The fate and residence time of the MAs in sediments depends on their production, consumption and sorption behaviour. They are weak bases and the protonated forms (e.g. $\mathrm{CH}_{3} \mathrm{NH}_{3}{ }^{+}$) predominate at seawater $\mathrm{pH}$. This means that they are soluble in porewaters but can also adsorb onto particles, with the clay mineral and organic matter content of the sediment solid-phase influencing the degree of adsorption (Wang \& Lee 1990).
This study aimed to improve the understanding both of tidal influence on MA cycling and of the apparent coupling between organisms inhabiting tidal flats and their direct influence on the $\mathrm{N}$ cycle, focussing on Ruditapes decussatus (L.), numbers of which were greatly enhanced at one of the sampling sites. The sampling strategy was as follows: at one site, sediment samples were collected over a short timescale $(2.5 \mathrm{~h})$ encompassing sediment exposure and the early stages of tidal inundation to measure background concentrations of the MAs and to monitor possible abrupt changes in MMA, DMA and TMA concentrations in the sediment porewaters and solid-phase. The clam $R$. decussatus and sediment samples were collected from a second site, both before and shortly after inundation, to determine the potential contribution of $R$. decussatus to MA cycling. The results are interpreted in terms of the sediment characteristics of the Ria Formosa, and the occurrence and behaviour of $R$. decussatus, and its potential contribution to dissolved nitrogen concentrations in the Ria Formosa.

\section{MATERIALS AND METHODS}

Ria Formosa. The Ria Formosa barrier island system, located in the Algarve, Portugal (Fig. 1), protects a large mesotidal lagoon extending along the eastern part of its south coast $\left(36^{\circ} 58^{\prime} \mathrm{N}, 8^{\circ} 02^{\prime} \mathrm{W}\right.$ to $37^{\circ} 03^{\prime} \mathrm{N}$, $7^{\circ} 32^{\prime} \mathrm{W}$ ). It includes a large inter-tidal zone about $55 \mathrm{~km}$ long $(\mathrm{E}-\mathrm{W})$ and about $6 \mathrm{~km}(\mathrm{~N}-\mathrm{S})$ at its widest point. This zone is separated from the sea by 2 peninsular sand spits and 5 barrier islands. There are 6 inlets that allow exchanges of water with the Atlantic Ocean (Vila-Concejo et al. 2003). The average water depth of the lagoon is $<3 \mathrm{~m}$. The tidal regime is semi-diurnal, with average amplitudes ranging from $0.7 \mathrm{~m}$ for neap tides to about $2.8 \mathrm{~m}$ for spring tides. Bebianno (1995) estimated a 50 to $75 \%$ exchange of the lagoon water with the ocean within a few tidal cycles, although the inner regions are less affected by the tides than the outer ones. Information on the nitrogen benthic metabolism in the lagoon is scarce, despite the fact that Newton et al. (2003) reported several indicators within the

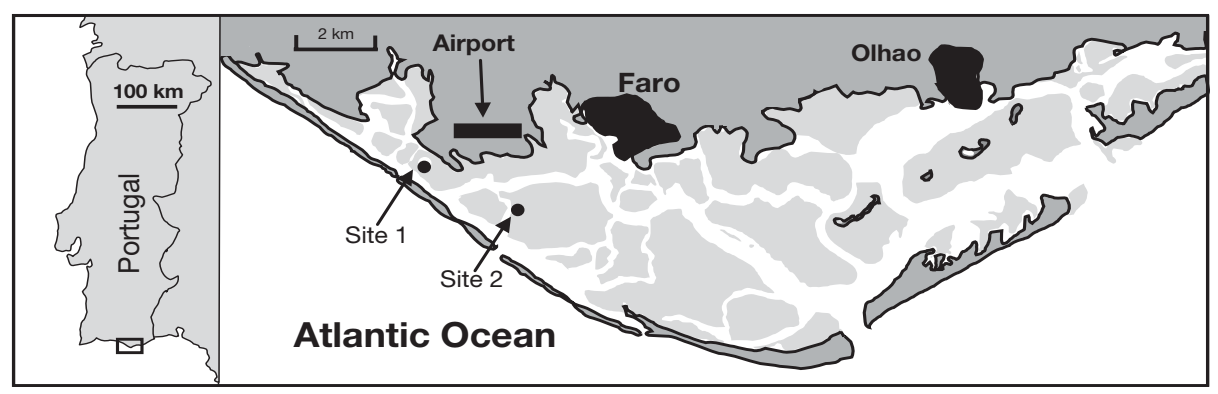

Fig. 1. Location of the Ria Formosa lagoon with sampling sites indicated. Samples RF1 to RF4 were collected from a mudflat $50 \mathrm{~m}$ from the bridge (west of Site 1), while the other sediment and clam samples were collected in the clam beds at Site 2. For sediment descriptions at each site, please refer to the text 
Ria Formosa which suggest a shift from a pristine to a nutrified (N-enriched) system during the last 2 decades. Results from other studies suggest that high benthic-pelagic coupling occurs during nitrogen cycling. Machás et al. (2003) reported ${ }^{15} \mathrm{~N}$-enrichment in the macroalgae Ulva sp., seagrasses and marsh plants on a longitudinal transect extending from the outer to the inner Ria Formosa lagoon, indicating either high benthic turnover of $\mathrm{N}$ or significant inputs of isotopically heavy $\mathrm{N}$ from sewage.

Economic exploitation of the resources of the Ria Formosa relies heavily on mariculture in natural sandflats of the clam Ruditapes decussatus, the major bivalve produced in Portugal. In fact, Ria Formosa production of $R$. decussatus accounts for $95 \%$ of the national total of this species (GEPP 1992). While natural macrofaunal density in the sandy sediments of the Ria Formosa is 40 to 200 ind. $\mathrm{m}^{-2}$ (Sprung 1994), $R$. decussatus is seeded (i.e. juvenile clams are introduced into a semi-controlled environment, named the clam rearing plot) to a maximum density of 600 ind. $\mathrm{m}^{-2}$ in sandy sediments (ECORUDI project unpubl. data). Sandy sediments are preferred for seeding as waste products are more easily flushed away from the clams by the incoming tide.

Sampling. Two sites, with contrasting sediment characteristics, were used for sampling. Sediments at Site 1 were typically cohesive, with combined silt and clay content accounting for roughly $60 \%$ of the total particle mass (see Table 1). Site 2 was a sandflat, used for the mariculture of Ruditapes decussatus, and had grain sizes ranging from fine to very coarse sand.

Site 1: Samples were collected during September 2000 in the vicinity of the bridge crossing from the mainland to the barrier islands (Fig. 1). Four sets of cores were taken over a period of $2.5 \mathrm{~h}$, encompassing sediment exposure and the onset of tidal inundation of the site. Duplicate sediment core samples were collected using acrylic core liners $(72 \mathrm{~mm}$ i.d. $\times 100 \mathrm{~mm}$ length) at timed intervals until the sediments were inundated (flooded) by the incoming tide. The first sample (RF1) was collected $2 \mathrm{~h}$ before flooding, RF2 was taken $1 \mathrm{~h}$ before flooding, RF3 was collected as the incoming water reached the sampling site and the final sample (RF4) was taken $0.5 \mathrm{~h}$ after initial inundation of the sediments. Extraction of porewater from the sampled cores was undertaken on-site, immediately after coring. Cores were sectioned at $10 \mathrm{~mm}$ intervals from 0 to $50 \mathrm{~mm}$ depth and duplicate sections from each depth interval were combined for extraction of porewater. Extraction was carried out under nitrogen using a pressurized sediment squeezer constructed at the University of the Algarve, which could simultaneously collect samples of porewater from up to 5 sediment sections. Extraction chambers were connected to a nitrogen gas cylinder to maximize extraction efficiency and to reduce sample contact with oxygen. The extracted porewater was diverted into acid-washed glass vials through $0.45 \mu \mathrm{m}$ cellulose acetate filter membranes and acidified with 1 drop of concentrated hydrochloric acid (11.6 M). Sediment and porewater samples were brought back to the laboratory in a cool box and frozen immediately $\left(-20^{\circ} \mathrm{C}\right)$ for transport back to the UK. In addition, 6 mini-cores $(27 \mathrm{~mm}$ cross section, $150 \mathrm{~mm}$ length) were collected simultaneously with the first sample and immediately brought back to the laboratory for electrode studies. In the laboratory, they were put in a mini-flume tank capable of tidal simulation over a set of cores. Details of the tank are available elsewhere (Rocha et al. 2001). Surface water from the tidal channel bathing the sampling site was collected for the tidal simulation, and the temperature in the mini-flume was maintained equal to the water temperature at the time of collection by means of an inline thermostat-controlled cooler. The time of flooding of the cores in the mini-flume was set for the same time that flooding would occur at the sampling site, and redox and $\mathrm{pH}$ profiles were acquired $1 \mathrm{~h}$ before and $1 \mathrm{~h}$ after flooding of the cores took place. Oxygen profiles were also recorded at the onset of flooding.

Site 2: Sediment cores (50 mm depth) and individual clams Ruditapes decussatus were collected. The first core and set of clams were collected $1 \mathrm{~h}$ before the incoming tide had reached the site. The second sediment core and clams were collected just after inundation of the site. Each of the 2 clam sample sets contained 10 individuals. Once collected, the cores were sealed and the clams placed in plastic sample bags. All samples were then placed in a cool box for transportation to the laboratory. On arrival, sediment was wiped from the clam shells and their mantles opened. The entrapped water was transferred into a measuring cylinder to record the volume and then immediately transferred to an acid-washed glass vial and stored frozen for analysis. The soft tissue of the clams was then carefully removed with a knife and homogenized in a blender without addition of any solution (each sample set was blended separately). The clam tissue from each sample set was then weighed and analysed separately. Sediment cores were sectioned at $50 \mathrm{~mm}$ intervals and the top $50 \mathrm{~mm}$ were then homogenized and transferred to acid-washed Nalgene bottles. The sediment, clam mantle-cavity water and clam tissue samples were then frozen $\left(-20^{\circ} \mathrm{C}\right)$ for analysis in the UK. Samples were analysed within 2 wk of collection.

Physico-chemical measurements. The water content of sediments was calculated through weight loss after heating of unfiltered sediments in an oven $\left(105^{\circ} \mathrm{C}\right.$, $48 \mathrm{~h})$. Grain size measurements were performed on freeze-dried sediment samples using a Malvern Long- 
bed Mastersizer-X, with wet sample unit MS17, according to ISO13320. Samples were analysed after removal of organics through wet oxidation using $6 \%$ hydrogen peroxide (Smith 1975) and data were recorded with Mastersizer-X software, Version 2.18. The dimensionless partition coefficient, $K^{*}$, for each MA was determined by dividing the solid-phase MA concentrations by the porewater MA concentrations after both pools had been normalised to mol kg ${ }^{-1}$ bulk sediment.

Oxygen, pH and redox profiling. Vertical oxygen profiles were recorded using polarographic microelectrodes (Unisense) with an internal reference and guard cathode according to Revsbech (1989). Sensitive tips had a 2 to $7 \mu \mathrm{m}$ cross-section, and were introduced into the sediment in $250 \mu \mathrm{m}$ steps using a motorized 3 -axis manipulator. Electrodes were calibrated against the overlying water concentration, as determined by automated Winkler titration in triplicate. Typically, 90\% of the signal output was obtained in less than $0.2 \mathrm{~s}$, and stirring sensitivity was less than $1 \%$ of full scale. A linear relationship between output and concentration was assumed, and the signal in anoxic conditions (dark current) was calibrated both with oxygen-stripped saline water and in anoxic sediment while profiling (Revsbech 1989). Redox (ORP-oxidation-reduction potential) profiles were recorded simultaneously, using a platinum combination redox microelectrode (Mascom) placed in parallel with the oxygen sensor in a multielectrode holder on the micromanipulator. Output was calibrated against Quinhydrone-saturated $\mathrm{pH}$ buffers. $\mathrm{pH}$ profiles were recorded using the same setup, with a different motorized manipulator and $\mathrm{pH}$ glass combination microelectrodes (Mascom), calibrated against regular saline $\mathrm{pH}$ buffers. Redox and $\mathrm{pH}$ microlectrodes had a 2 to $7 \mu \mathrm{m}$ sensing tip cross section, negligible stirring sensitivity (less than $0.05 \%$ full-scale), and had a typical $90 \%$ signal output in under $0.2 \mathrm{~s}$. All shown profiles are averages of 3 fullgradient measurements, and value oscillation is represented as the SD of the mean for each depth.

Determination of the MAs. The MAs were measured in porewater and sediment samples from Site 1, and in sediment, mantle cavity water and clam tissue samples from Site 2. Aqueous samples (porewaters and mantle cavity waters) were transferred to an acid-washed volumetric flask, and then diluted to $50 \mathrm{ml}$ in a solution of synthetic seawater, adjusted to $\mathrm{pH} 12$ through the addition of $2 \mathrm{ml}$ of $6 \mathrm{M} \mathrm{NaOH}$. Cyclopropylamine (CPA) was added as an internal standard and the MAs were then pre-concentrated through microdiffusion in a fan oven $\left(24 \mathrm{~h}, 60^{\circ} \mathrm{C}\right)$ as described by Abdul-Rashid et al. (1991). The pre-concentrated samples (i.e. MAs in $0.2 \mathrm{ml}$ of $0.02 \mathrm{M} \mathrm{HCl}$ ) were re-adjusted to $\mathrm{pH} 12$ by adding $\mathrm{NaOH}$ $(0.05 \mathrm{ml}, 0.5 \mathrm{M})$ and injected onto a Fisons 8000 Series packed column gas chromatograph equipped with a nitrogen-phosphorus detector (GC-NPD). The GC column ( $2 \mathrm{~m}$ ) was packed with Carbopack B (60 to 80 mesh) coated with Carbowax 20M (4\%) and $\mathrm{KOH}(0.8 \%)$. Peak areas were recorded using a PC equipped with a Chromcard for Windows (Thermo Finnigan).

Filtered sediment and tissue samples were also analysed by microdiffusion. The solid sample $(1 \mathrm{~g}$ of filtered sediment or 4 to $5 \mathrm{~g}$ of clam tissue) was placed in a microdiffusion flask and $48 \mathrm{ml}$ of $2 \mathrm{M} \mathrm{LiCl}$ solution containing CPA was added to desorb exchangeable MAs (Wang \& Lee 1994). The sample was gently mixed and the solution adjusted to $\mathrm{pH} 12$ by addition of $2 \mathrm{ml}$ of $6 \mathrm{M} \mathrm{NaOH}$. The flask was immediately sealed and the microdiffusion carried out as detailed above. Water for blanks and standard solutions was obtained from a SERADEST S600 system $\left(<0.1 \mu \mathrm{S} \mathrm{cm}{ }^{-1}\right.$ conductivity). Stock standard solutions of the MAs (1 M) were prepared from their chloride salts and $1 \mathrm{ml}$ of concentrated $\mathrm{HCl}$ was added as a preservative. These solutions were then refrigerated and checked regularly for degradation. Working standard dilutions were prepared as required. Samples were analyzed in duplicate and the measurement precision for the analytes was below $10 \%$ for all samples with 1 exception (11.4\%).

\section{RESULTS}

\section{Site 1}

\section{Sediment characteristics}

The combined silt and clay fractions ranged from 58 to $62 \%$, with RF3 (82\%) being the exception (Table 1). There was a noticeable change in water content between the top $20 \mathrm{~mm}$ and the rest of the core during the sampling period. The water content of the 0 to

Table 1. Physical characteristics of cores RF1 to RF4, taken from Site 1. Grain size measurements are depth-averaged

\begin{tabular}{|c|c|c|c|c|c|}
\hline Core & Time & $\begin{array}{l}\text { Grain } \\
\text { size }\end{array}$ & $\begin{array}{c}\text { Size fraction } \\
(\%)\end{array}$ & $\begin{array}{c}\text { Water } \\
\text { content }\end{array}$ & $(\%)$ \\
\hline \multirow[t]{3}{*}{ RF1 } & \multirow{3}{*}{$\begin{array}{l}2 \mathrm{~h} \text { before } \\
\text { inundation }\end{array}$} & Sand & 38 & \multirow[t]{2}{*}{$0-20 \mathrm{~mm}$} & \multirow[t]{2}{*}{49} \\
\hline & & Silt & 52 & & \\
\hline & & Clay & 20 & $20-50 \mathrm{~mm}$ & 55 \\
\hline \multirow[t]{3}{*}{ RF2 } & \multirow{3}{*}{$\begin{array}{l}1 \mathrm{~h} \text { before } \\
\text { inundation }\end{array}$} & Sand & 37 & \multirow[t]{2}{*}{$0-20 \mathrm{~mm}$} & \multirow[t]{3}{*}{49} \\
\hline & & Silt & 53 & & \\
\hline & & Clay & 10 & $20-50 \mathrm{~mm}$ & \\
\hline \multirow[t]{3}{*}{ RF3 } & \multirow{3}{*}{$\begin{array}{l}\text { Onset of } \\
\text { inundation }\end{array}$} & Sand & 16 & \multirow[t]{2}{*}{$0-20 \mathrm{~mm}$} & \multirow[t]{3}{*}{68} \\
\hline & & Silt & 72 & & \\
\hline & & Clay & 12 & $20-50 \mathrm{~mm}$ & \\
\hline \multirow[t]{3}{*}{ RF4 } & \multirow{3}{*}{$\begin{array}{l}0.5 \mathrm{~h} \text { after } \\
\text { inundation }\end{array}$} & Sand & 42 & \multirow[t]{2}{*}{$0-20 \mathrm{~mm}$} & \multirow[t]{2}{*}{76} \\
\hline & & Silt & 48 & & \\
\hline & & Clay & 10 & $20-50 \mathrm{~mm}$ & 74 \\
\hline
\end{tabular}



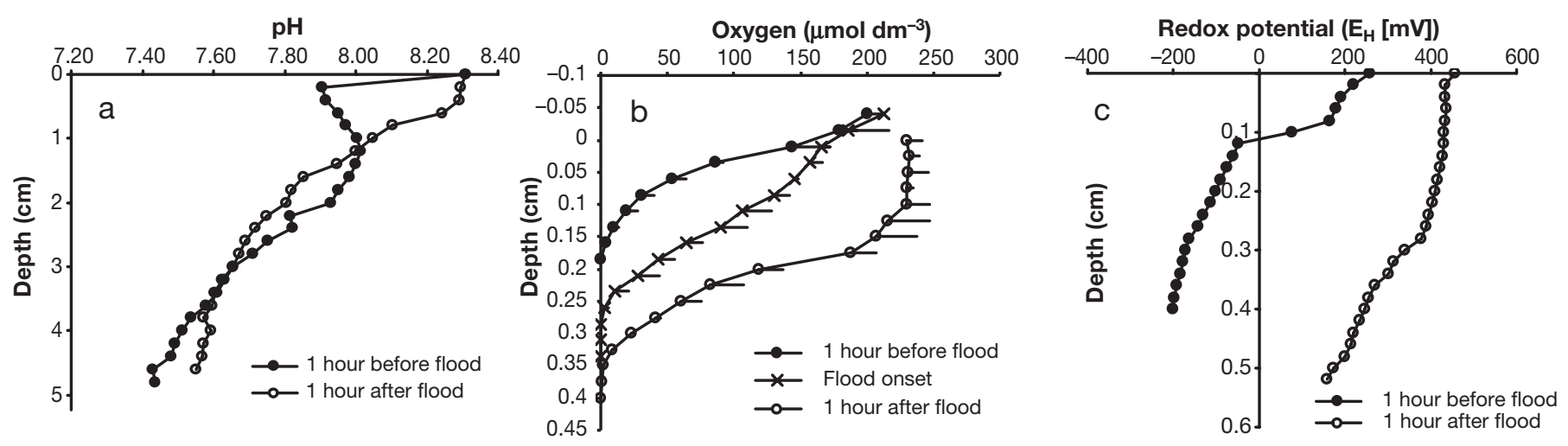

Fig. 2. Sediment profiles of (a) $\mathrm{pH}$, (b) dissolved oxygen and (c) redox potential taken at various stages of simulated tidal inundation in a flume system

20 mm section was constant (49\%) in RF1 and RF2 (the cores taken before inundation of the site), compared with a mean value of $58 \%$ below $20 \mathrm{~mm}$ in these cores. The water content increased for the 0 to $20 \mathrm{~mm}$ core section at the onset of tidal inundation (68\%, RF3), compared with $50 \%$ below $20 \mathrm{~mm}$. A further increase was observed in the final core, which had a water content of $76 \%$ (RF4), while the water content below $20 \mathrm{~mm}$ had increased to $74 \%$.

High resolution multi-electrode measurements were made $1 \mathrm{~h}$ before simulated tidal inundation and $1 \mathrm{~h}$ after inundation (Fig. 2). The core was anaerobic below $1 \mathrm{~mm}$ depth before inundation and $\mathrm{pH}$, redox potential and dissolved oxygen concentrations had all changed significantly after inundation. Before inundation, the $\mathrm{pH}$ decreased from 8.31 at the sediment surface to 7.9 at $2 \mathrm{~mm}$ (Fig. 2a). The $\mathrm{pH}$ then increased to 8.01 before gradually decreasing to 7.44 at $48 \mathrm{~mm}$. After inundation, the $\mathrm{pH}$ was 8.31 at the sediment surface but decreased gradually to 8.00 at $12 \mathrm{~mm}$. Below this depth, the $\mathrm{pH}$ profile was very similar to that observed before inundation. Dissolved oxygen included a profile recorded at the onset of inundation (Fig. 2b). Dissolved oxygen decreased from a surface value of $201 \mu \mathrm{mol} \mathrm{l} \mathrm{l}^{-1}$ to 0 at $2.2 \mathrm{~mm}$. At the onset of inundation, the depth of dissolved oxygen had increased to $3.5 \mathrm{~mm}$, and was detected down to $3.8 \mathrm{~mm}$ $1 \mathrm{~h}$ after inundation. The redox boundary, which indi- cates the change from aerobic to anaerobic conditions, occurred at 0.8 to $1.2 \mathrm{~mm}$ before inundation (Fig. 2c). One hour after inundation, the redox boundary was not visible above $5 \mathrm{~mm}$ depth.

\section{Partition coefficients}

$K^{*}$ for all MAs were highest in RF1 and RF2 and decreased with depth (Table 2, Fig. 3). The $K^{*}$ values in RF3 and RF4 were much lower and a systematic decrease with depth was not observed. $K^{*}$ for TMA was highest in RF1 (118 at 0 to $10 \mathrm{~mm}$ depth) and decreased with time (14 in RF2 down to 0 in RF4, both at 0 to $10 \mathrm{~mm}$; Fig. 3a). This decline in $K^{*}$ was concurrent with a decrease in solid-phase TMA concentrations with time, but also with the increase of water content in the surface layers after inundation. $K^{*}$ values for both DMA and MMA increased from RF1 to RF2 (up to 109 and 338, respectively), then decreased at the onset of inundation and remained virtually unchanged thereafter (Fig. 3b,c).

\section{MA concentrations (porewaters)}

MAs were detected in the porewaters throughout the sampling period (see Table 2 and Fig. 4). The concentrations of all 3 analytes were virtually unchanged in

Table 2. Range of MA concentrations measured in the porewater and solid-phase of cores from Site 1. See text for details on the calculation of $K^{*}$, the dimensionless adsorption coefficient

\begin{tabular}{|c|c|c|c|c|c|c|c|c|c|}
\hline \multirow[t]{2}{*}{ Core } & \multicolumn{3}{|c|}{ Porewater ( $\mu \mathrm{mol} \mathrm{kg}{ }^{-1}$ bulk sediment) } & \multicolumn{3}{|c|}{ Solid phase ( $\mu \mathrm{mol} \mathrm{kg}^{-1}$ bulk sediment) } & \multirow{2}{*}{$K^{*}{ }_{\text {MMA }}$} & \multirow{2}{*}{$K^{*}{ }_{\text {DMA }}$} & \multirow{2}{*}{$K^{*}$ TMA } \\
\hline & MMA & DMA & TMA & MMA & DMA & TMA & & & \\
\hline RFA1 & $0.05-0.10$ & $0.19-0.51$ & $0.58-1.49$ & $4.15-7.13$ & $6.20-9.17$ & $59.67-72.96$ & $40-114$ & $12-46$ & $40-118$ \\
\hline RFA2 & $0.05-0.11$ & $0.16-0.53$ & $0.58-1.50$ & $16.70-24.58$ & $11.37-17.09$ & $5.21-8.23$ & $181-338$ & $27-109$ & $5-14$ \\
\hline RFA3 & $6.44-8.26$ & $0.31-0.47$ & $1.15-1.33$ & $6.74-12.10$ & $4.19-7.31$ & $3.68-8.51$ & $1-2$ & $13-20$ & $3-6$ \\
\hline RFA4 & $5.43-7.19$ & $0.26-0.63$ & $0-0.25$ & $18.49-39.40$ & $6.69-9.05$ & $0-0.51$ & $3-6$ & $14-26$ & $2-7^{*}$ \\
\hline
\end{tabular}




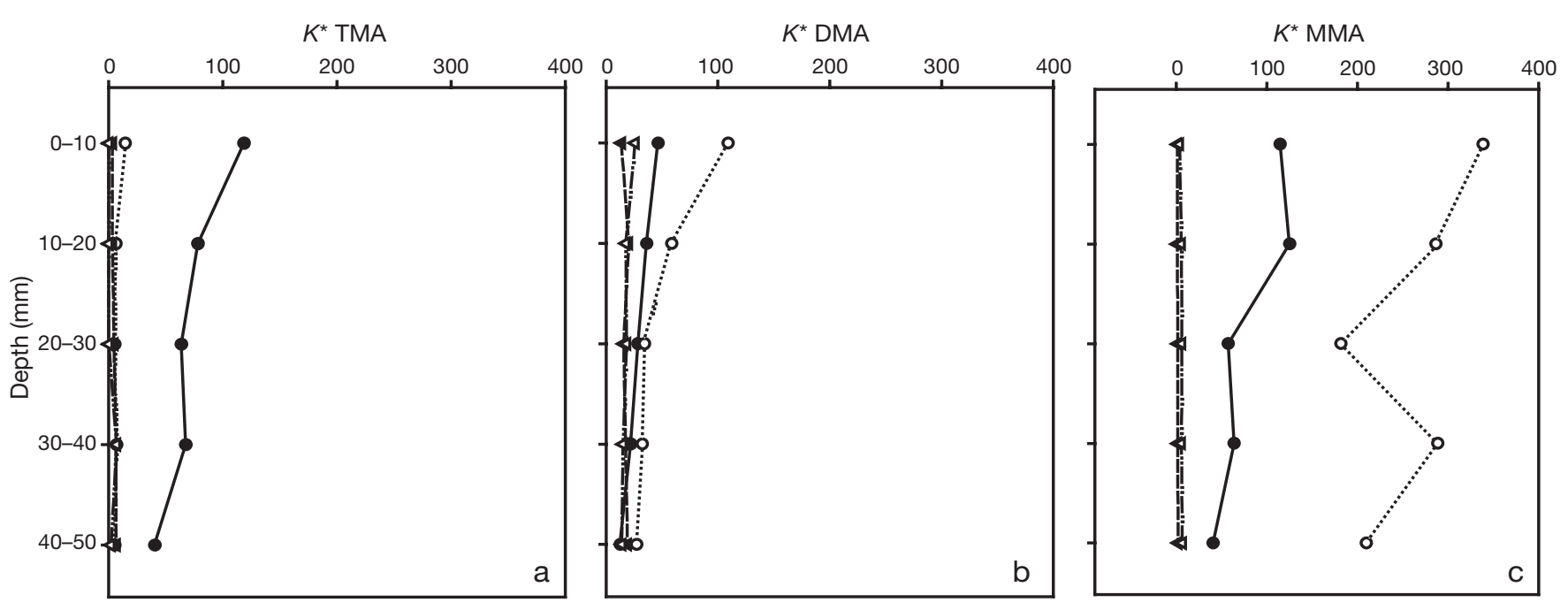

Fig. 3. Measurements of $K^{*}$, the dimensionless adsorption coefficient, for (a) MMA, (b) DMA and (c) TMA in cores taken from Site 1 . Symbols refer to $K^{*}$ calculated from samples taken at the following times: $(\bullet) 2 \mathrm{~h}$ before flooding (RF1); (o) $1 \mathrm{~h}$ before flooding (RF2); (ム) flooding begins (RF3); $(\Delta) 0.5 \mathrm{~h}$ after flooding begins (RF4). See text for details on how $K^{*}$ was calculated

the cores taken prior to inundation. TMA was the most abundant MA in the porewaters before inundation at concentrations up to $1.50 \mu \mathrm{mol} \mathrm{kg} \mathrm{kg}^{-1}$ bulk sediment (Fig. 4a). Its core average concentrations increased at the onset of inundation of Site 1 (core RF3), where an increase in the top $30 \mathrm{~mm}$ of the core was apparent, followed by depletion in RF4 where TMA was not detected in the top $20 \mathrm{~mm}$ of the core. Of the $3 \mathrm{MAs}$, DMA showed least variation in concentration throughout the sampling series (Fig. 4b) and analysis by a Student's $t$ test revealed that DMA concentrations did not vary significantly throughout the sampling period $(p<0.05)$.
MMA was the least abundant MA in cores RF1 and RF2 (Fig. 4c). However, its concentrations had increased by 2 orders of magnitude in RF3 (6 to $8 \mu \mathrm{mol} \mathrm{kg}{ }^{-1}$ bulk sediment) and then decreased only slightly in RF4 (5 to $7 \mu \mathrm{mol} \mathrm{kg}{ }^{-1}$ bulk sediment).

\section{MA concentrations (solid phase)}

TMA was the most abundant MA in RF1 (60 to $73 \mu \mathrm{mol} \mathrm{kg}{ }^{-1}$ bulk sediment) and decreased constantly from pre to post flooding (Fig. 5). Its concentrations had
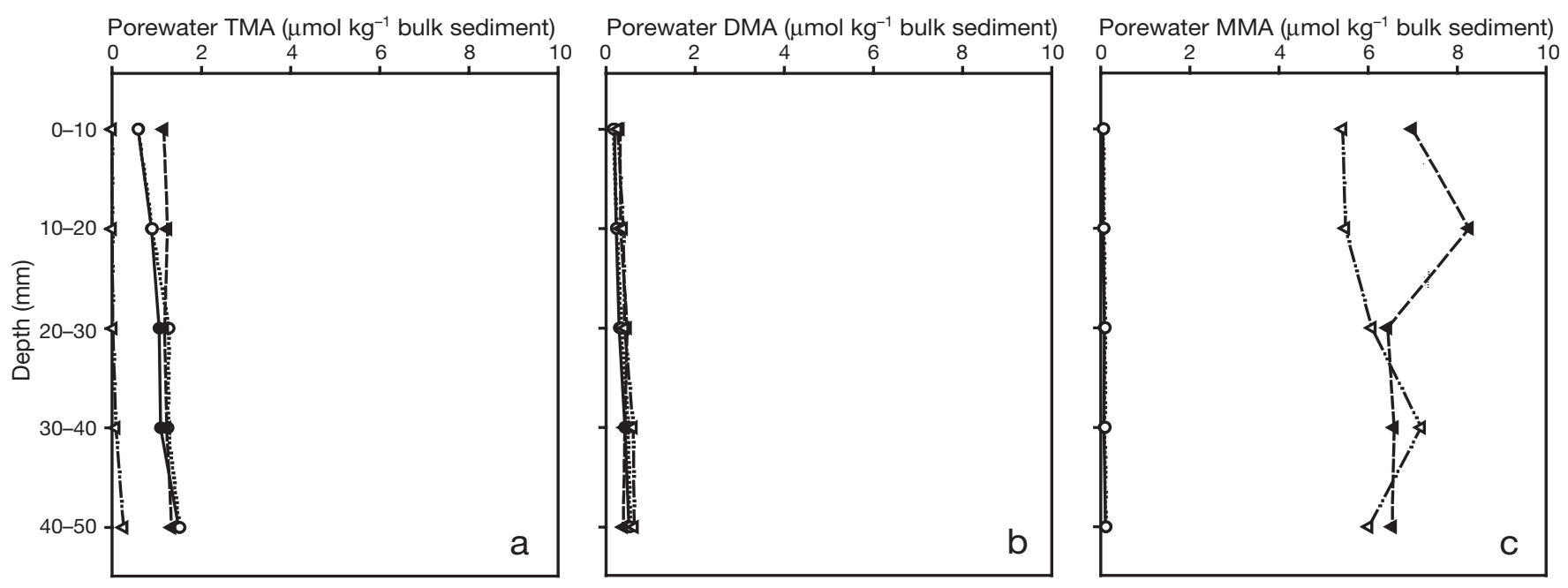

Fig. 4. Porewater concentrations of (a) TMA, (b) DMA and (c) MMA from Site 1. Concentrations measured refer to the porewater MA concentration in $1 \mathrm{~kg}$ of bulk sediment (i.e. porewater and solid phase combined). Symbols used reflect samples taken at

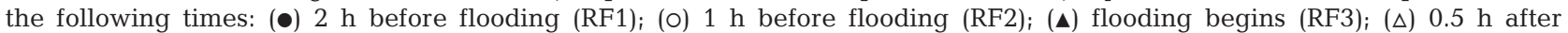
flooding begins (RF4) 

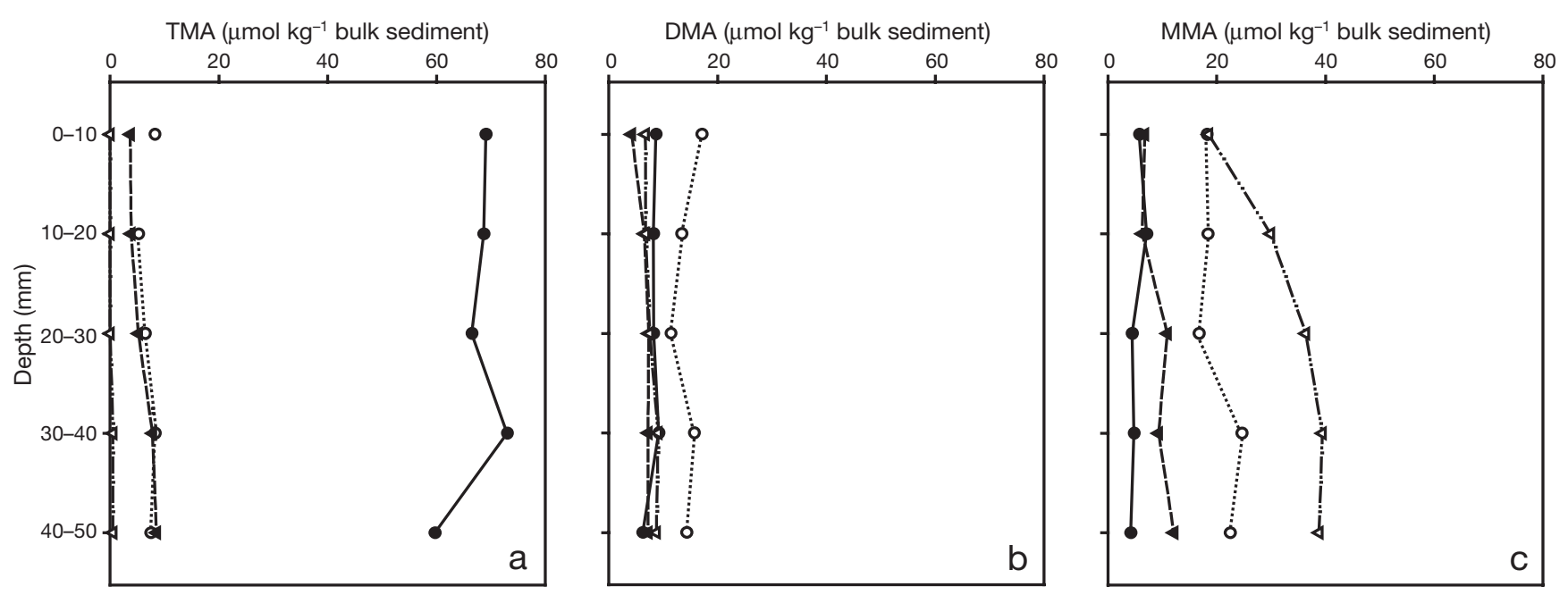

Fig. 5. Solid-phase concentrations of (a) TMA, (b) DMA and (c) MMA in cores taken from Site 1. Concentrations measured refer to the solid phase MA concentration in $1 \mathrm{~kg}$ of bulk sediment. Symbols used reflect samples taken at the following times:

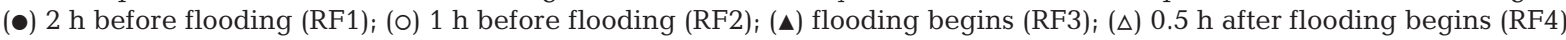

decreased by an order of magnitude in RF2 ( 5 to $8 \mu \mathrm{mol}$ $\mathrm{kg}^{-1}$ bulk sediment). The next significant variation was observed in RF4, where TMA concentrations decreased to 0 above $30 \mathrm{~mm}$ and only reached a maxi-

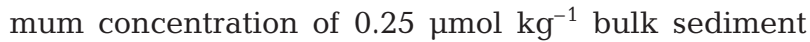
throughout the sampling depth. Solid-phase DMA concentrations showed little variation with time and with depth, replicating behaviour observed for the dissolved phase. Highest DMA concentrations occurred in RF2 (11 to $17 \mu \mathrm{mol} \mathrm{kg}{ }^{-1}$ bulk sediment). However, the range of DMA concentrations was 4 to $9 \mu \mathrm{mol} \mathrm{kg}{ }^{-1}$ bulk sediment for the other 3 cores, and a Student's $t$-test verified that there was no significant variation in DMA abundance in these cores $(\mathrm{p}<0.05)$. MMA concentrations were highest in RF2 (17 to $25 \mu \mathrm{mol} \mathrm{kg}{ }^{-1}$ bulk sediment) and RF4 (18 to $39 \mu \mathrm{mol} \mathrm{kg}{ }^{-1}$ bulk sediment), as shown in Fig. 5c. Concentrations varied significantly between cores and it can be seen that MMA accumulated in the solid phase before inundation (RF1, RF2), thereafter decreased at the onset of inundation (RF3) and accumulated in the last core (RF4), where concentrations increased with depth.

\section{Site 2}

\section{Sediment characteristics}

Sediment at Site 2 consisted almost entirely of quartz sand, with over $40 \%$ composed of very coarse to medium sand and a finer fraction ( $60 \%$ by weight) constituting very fine sand. It was not possible to retain porewaters within the cores during sampling, which meant that neither the porewater content of the sedi-
Table 3. Concentrations of the MAs in samples of Ruditapes decussatus and sediment taken from Site 2 before and after tidal inundation (nd: not detected). Mantle cavity water concentrations are expressed in mol $\mathrm{kg}^{-1}$ since $1 \mathrm{ml}$ of sample weighed $1 \mathrm{~g}$

\begin{tabular}{|lccc|}
\hline Sample & $\begin{array}{c}\mathrm{MMA} \\
\left(\mathrm{mmol} \mathrm{kg}^{-1}\right)\end{array}$ & $\begin{array}{c}\mathrm{DMA} \\
\left(\mathrm{mmol} \mathrm{kg}^{-1}\right)\end{array}$ & $\begin{array}{c}\mathrm{TMA} \\
\left(\mathrm{mmol} \mathrm{kg}^{-1}\right)\end{array}$ \\
\hline Clam tissue & & & \\
$\quad$ Before inundation & 0.51 & 0.48 & 191.48 \\
$\quad$ After inundation & 0.18 & 0.45 & 36.10 \\
Change & -0.33 & -0.03 & -155.38 \\
Mantle cavity water & & & \\
$\quad$ Before inundation & 0.003 & 0.001 & 0.013 \\
After inundation & 0.003 & $\mathrm{nd}$ & 0.107 \\
Change & 0 & -0.001 & 0.094 \\
Sediment (0.4 porosity) & & & \\
$\quad$ Before inundation & 0.032 & 0.010 & 0.073 \\
After inundation & 0.017 & 0.001 & 0.909 \\
Change & -0.015 & -0.009 & 0.836 \\
\hline
\end{tabular}

ments nor the porewater concentrations of the analytes could be determined. Solid-phase MA concentrations are expressed in mol kg-1 bulk sediment in Table 3, assuming an average porewater content of $40 \%$ at the site in September (Rocha et al. 2001).

\section{MA concentrations (sediment solid phase)}

The 3 MAs were present in the sediments from Site 2 sampled before and after tidal inundation (Table 3). TMA was the most abundant MA on each occasion. 
TMA concentrations increased from $73 \mu \mathrm{mol} \mathrm{kg}{ }^{-1}$ bulk sediment, in the sediment core taken before inundation, to $909 \mu \mathrm{mol} \mathrm{kg}{ }^{-1}$ bulk sediment after inundation. DMA decreased between samples (from 10 to $1 \mu \mathrm{mol}$ $\mathrm{kg}^{-1}$ bulk sediment), as did MMA (from 32 to $17 \mu \mathrm{mol}$ $\mathrm{kg}^{-1}$ bulk sediment).

\section{Clam tissue and mantle cavity water}

TMA was the most abundant MA in the clam tissue and mantle cavity water samples analyzed (Table 3). Tissue concentrations of TMA were higher than in any of the other samples analyzed, and decreased from $191 \mathrm{mmol} \mathrm{kg}^{-1}$ before inundation to $36 \mathrm{mmol} \mathrm{kg}^{-1}$ after inundation. DMA and MMA were 4 orders of magnitude less abundant than TMA in these samples. MMA concentrations decreased between samples (510 to $180 \mu \mathrm{mol} \mathrm{kg}{ }^{-1}$ bulk sediment), while a smaller decrease was observed for DMA (480 to $450 \mu \mathrm{mol} \mathrm{kg}{ }^{-1}$ bulk sediment). The mantle cavity water was defined as water drained from the clam on opening the shell. Concentrations are expressed in $\mathrm{mol} \mathrm{kg} \mathrm{kg}^{-1}$ as $1 \mathrm{ml}$ of mantle cavity water weighed $1 \mathrm{~g}$. TMA was the most abundant MA in the mantle cavity water (Table 3). In contrast to the change observed for clam tissue, TMA concentrations increased between samples (13 to $107 \mu \mathrm{mol} \mathrm{kg}^{-1}$ ). DMA was present at $1 \mu \mathrm{mol} \mathrm{kg}^{-1}$ before inundation and was not detected after inundation, while MMA concentrations did not change (3 $\left.\mu \mathrm{mol} \mathrm{kg} \mathrm{kg}^{-1}\right)$.

\section{DISCUSSION}

\section{Cycling of methylamines through tidal inundation in cohesive sediments}

Grain size analysis of sediments from Site 1 revealed no distinct layering (Table 1) but the water content of the top $20 \mathrm{~mm}$ was noticeably lower than in the rest of the core before inundation (cores RF1 and RF2). Rocha (1998), studying $\mathrm{NH}_{4}^{+}$cycling in intertidal sediments of the Sado Estuary, Portugal, observed that the high percentage of sand in that sediment, coupled with high summer temperatures, led to dewatering of surface sediments as occurred at Site 1. Inundation then increased the water content in the top $20 \mathrm{~mm}$ of RF3, and throughout the core in RF4. Measurements on the flume core showed that tidal inundation increased the depth of oxygen penetration and the redox boundary in the sediment (Fig. 2). The increased water content throughout RF4 suggested that the sediment was oxygenated to a greater depth than was observed in the flume system, though this would also be dependent on the sediment oxygen demand.

Porewater concentrations of the 3 MAs were virtually unchanged in the 2 cores taken before inundation (Fig. 4), while solid-phase TMA was consumed; its con-

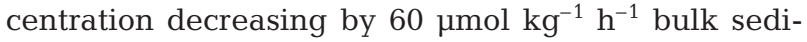
ment in the first hour of sampling (i.e. between RF1 and RF2). The corresponding increase in solid-phase MMA and DMA did not balance all of the TMA consumed and it was presumed that production of $\mathrm{NH}_{4}{ }^{+}$ could account for this, a scenario which has been reported for coastal marine sediments by Kim et al. (2003). TMA was still present in the porewater and solid phase at the onset of inundation (RF3), but was virtually absent in core RF4 (Figs. 4a \& 5a, respectively). Flushing of sediments by the incoming tide is a possible reason but this should have removed all MAs from the sediment. The introduction of oxygenated seawater may have enabled oxidation of TMA to TMAO to proceed (Kim et al. 2003), but this compound cannot be measured using our microdiffusion technique.

Although basic organic nitrogen (ON) species have been shown to adsorb more strongly to sediments than other compounds from the ON fraction, adsorption of MAs is known to be reversible (Wang \& Lee 1995), which helps explain the consumption of solid-phase TMA. TMA forms the most stable MA cation (i.e. $\left.\left[\left(\mathrm{CH}_{3}\right)_{3} \mathrm{NH}\right]^{+}\right)$as methyl substituents reduce the positive charge on the $\mathrm{N}$ atom (Solomons \& Fryhle 2000). It appears that MAs bind to the sediment solid phase through interaction with anionic exchange sites on the particle surface (Wang \& Lee 1990) and it follows that a reduction in the positive charge on the $\mathrm{N}$ atom will reduce the binding energy of the TMA cation to the solid phase, increasing its bioavailability. A similar rate of anaerobic TMA consumption (i.e. $60 \mu \mathrm{mol} \mathrm{kg}{ }^{-1} \mathrm{~h}^{-1}$ ) has been recently reported for coastal marine sediments (Kim et al. 2003), where TMA degradation was actually coupled with nitrate reduction. Methanogenic bacteria have also been shown to utilize MAs as noncompetitive substrates in sediments containing high sulphate concentrations (e.g. Oremland et al. 1982, King 1984, Franklin et al. 1988).

Porewater DMA concentrations did not vary significantly over the sampling period and inter-core solidphase concentrations were only significantly different in Core RF2, where the slight increase was probably due to TMA degradation. To our knowledge, a role for DMA, other than as an intermediate degradation product, has not been reported. Wang \& Lee (1994) found that Nereis diversicolor released MMA and TMA under stress, but much less DMA. Furthermore, when the organisms died, TMA and MMA concentrations in the surrounding waters increased up to several orders 
of magnitude (up to mmol $\mathrm{l}^{-1}$ ), while DMA did not increase at all. The Ruditapes decussatus samples analyzed in this study fitted the known paradigm, as they also contained more MMA and TMA than DMA. Porewater MMA concentrations increased significantly at the onset of inundation (RF3) and remained high while flooding of the site progressed (RF4) due to desorption of solid-phase MMA. Solid-phase MMA then increased in RF4 despite the further increase in porewater content (Table 1). This may have been due to a change in redox temporarily inhibiting mineralization of MMA to $\mathrm{NH}_{4}{ }^{+}$.

The $K^{*}$ values showed that the MAs were primarily associated with the solid-phase before inundation (Table 2). Rocha (1998) observed similar behaviour for $\mathrm{NH}_{4}{ }^{+}$in inter-tidal sediments from the Sado Estuary, and also that $K^{*}$ was higher than for sub-tidal sediments of the same average porosity (particularly in the surface sediments). The most striking change in $K^{*}$ occurred for MMA during inundation. Since sediment dewatering during exposure favours MMA adsorption, it is likely that hydration of the surface sediment caused repartitioning of MMA in the sediment. Such a process has also been described for $\mathrm{NH}_{4}{ }^{+}$(e.g. Rocha 1998, Morin \& Morse 1999).

It is interesting to note that the solid-phase TMA appeared to be readily consumed in the Site 1 sediments during exposure. Adsorption of different organic compounds has been invoked to explain the preservation of sedimentary organic carbon in various environments (e.g. Henrichs \& Sugai 1993). TMA can adsorb to sediments but its weak interaction with the particle surface may allow bacteria to consume adsorbed TMA (Wang \& Lee 1995).

\section{Cycling of MAs in Ruditapes decussatus}

Tissue and mantle cavity water measurements showed that Ruditapes decussatus is a potential source of TMA to sediments (Table 3) and that the sediment TMA concentrations after inundation were at least an order of magnitude higher than at Site 1. Porewater TMA has been shown to correlate positively with invertebrate density (Sørensen \& Glob 1987), and both Sørensen \& Glob (1987) and Wang \& Lee (1994) found that invertebrates release MAs under stress. The change in clam TMA concentration after inundation could have occurred either through excretion or oxidation of TMA to another chemical species (i.e. TMAO or another MA). It is also possible that the 2 processes occurred simultaneously, though MMA and DMA concentrations also decreased after inundation. The solidphase sediment TMA concentration before inundation was close to that observed in Core RF1 at Site 1 and to previously reported values for inter-tidal sediments (e.g. Wang \& Lee 1990, 1994, Abdul-Rashid et al. 1991, Fitzsimons et al. 2001). The increased TMA concentration in the sediment solid-phase at Site 2 after inundation indicates that some TMA was released by the clams. TMA is toxic (Anthoni et al. 1991, Marzo \& Curti 1997) and is generally converted to TMAO within living animals for use in osmoregulation (Seibel \& Walsh 2002).

It is unclear, therefore, why Ruditapes decussatus should contain high concentrations of TMA over the period of sediment exposure. TMAO is derived from dietary choline via its conversion to TMA by bacteria in the gut of marine animals (Seibel \& Walsh 2002), so some of the TMA measured may have originated from choline. Its conversion to TMAO requires oxygen, and excretion will only occur at the onset of inundation, when the clam recommences feeding and increases its oxygen input. The mean weights of tissue and mantle cavity water per clam were 2.36 and $1.25 \mathrm{~g}$, respectively ( $\mathrm{n}=20$ ), which equated to $451 \mu \mathrm{mol}$ TMA per clam and $0.35 \mu \mathrm{mol} \mathrm{O}_{2}$ in its mantle cavity water (assuming a dissolved $\mathrm{O}_{2}$ concentration of $281 \mu \mathrm{mol} \mathrm{kg}^{-1}$ ). Presuming that there is no transfer of water in or out of the clam during exposure, this means that there was only enough oxygen present to convert $0.14 \mu \mathrm{mol}$ of TMA to TMAO. The clam would, therefore, be forced to retain the TMA until inundation, when it could be oxidized, by oxygen-enriched water passing through the siphons during feeding, or immediately excreted, which would arguably be the simpler physiological solution.

Ruditapes decussatus is able to adapt to hypoxic environments, which it may experience at times during the summer (Sobral \& Widdows 1997, Sobral \& Fernandes 2004), so dealing with TMA at these levels may be well within the capability of the organism. The clam density at Site 2 was 10 ind. $\mathrm{kg}^{-1}$ bulk sediment, so if each clam excreted $365 \mu \mathrm{mol}$ of TMA (the concentration difference between samples), then, assuming a porewater content of $40 \%$ (Rocha et al. 2001) and $K^{*}=1$, the resulting solid-phase TMA concentration would be $2.19 \mathrm{mmol} \mathrm{kg}^{-1}$ bulk sediment. In fact, the TMA solid-phase concentration had increased by $0.84 \mathrm{mmol} \mathrm{kg}^{-1}$ bulk sediment after inundation, which was a substantial increase but less than the predicted amount. Sediment resuspension is a common feature of the Ria Formosa lagoon (Sobral \& Widdows 2000) and the fact that the clams excrete waste near the surface (Sobral \& Widdows 2000) increases the possibility of TMA being flushed from the sediment. Furthermore, $R$. decussatus is seeded in sandy sediments in the Ria Formosa to improve its survival rate throughout the growth period, due to the enhanced flushing of waste products from sediment. 
A study of MA desorption from sediments in the Thames estuary found that sandy sediments released MAs more readily than more cohesive sediments (M. F. Fitzsimons unpubl. data), so desorption of a fraction of the solid-phase TMA with inundation of Site 2 seems likely. Using the figures calculated above, flushing of porewater TMA and the 'missing' solid-phase TMA would result in a burst flux of $169 \mathrm{mmol} \mathrm{TMA} \mathrm{m}^{-2}$ from the sediment at the onset of inundation. Caetano et al. (1997) made summer measurements of $\mathrm{NH}_{4}{ }^{+}$concentrations in overlying water and sediments from the Ria Formosa during the first $20 \mathrm{~min}$ of tidal inundation. They found an almost 4-fold increase in the water col-

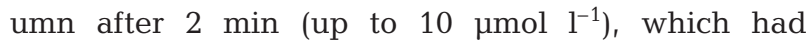
decreased to background concentrations after $15 \mathrm{~min}$. A concurrent decrease $\left(100 \mu \mathrm{mol} \mathrm{l}^{-1}\right)$ in sediment-associated $\mathrm{NH}_{4}{ }^{+}$was observed, with loosely exchangeable, adsorbed $\mathrm{NH}_{4}{ }^{+}$(64\% of the total $\mathrm{NH}_{4}{ }^{+}$flux) flushed out along with porewater $\mathrm{NH}_{4}{ }^{+}$. Assuming a water column depth of $3 \mathrm{~m}$, which is slightly higher than the $2.8 \mathrm{~m}$ average spring tide depth measured for the Ria Formosa, a flux of $169 \mathrm{mmol}$ TMA m $\mathrm{m}^{-2}$ would result, increasing the water column TMA concentration by approximately $60 \mu \mathrm{mol} \mathrm{l}^{-1}$ above the clam beds.

In summary, the temporal sampling carried out at Site 1 demonstrated that TMA can be rapidly metabolized during exposure of sediments from the Ria Formosa. It may be that that this pathway is coupled with methanogenesis or denitrification, which would have implications for $\mathrm{N}$ cycling in nutrified environments. The high density of clams in the sandflat appears to affect the $\mathrm{N}$ budget of the sediments, giving these organisms a role in the metabolism of $\mathrm{C}$ and $\mathrm{N}$. It also appears that the large numbers of Ruditapes decussatus in these sediments has the potential to significantly increase the flux of $\mathrm{N}$ to the water column, with implications for water quality in the Ria Formosa, which is showing evidence of nutrient enrichment. Future work will focus on the quantification, periodicity and seasonality of the flux of $\mathrm{N}$ from Ria Formosa sediments.

Acknowledgements. The authors are indebted to the University of Algarve, FCMA, and to the Centre for Marine and Environmental Research (CIMA) for hosting the work. M.D. was funded by a Middlesex University grant awarded to M.F.F. under the NFFR programme, which is gratefully acknowledged. C.R. was funded by the Portuguese National Foundation for Science and Technology (FCT) through contract SFRH/BPD/6042/2001. Research for this paper, on the Portuguese part, was co-financed by Project ECORUDI (Impact of variations in physico-chemical sediment characteristics on the ECOphysiology of RUDItapes decussatus in the Ria Formosa lagoon, PRAXIS/C/BIA/14220/1998). We also thank R. Hartley, University of Plymouth, for particle-size analysis and S. Vidal, S. Mesquita and J. Aníbal for help with field sampling. A. Vila-Concejo is thanked for the map of the Ria Formosa lagoon.

\section{LITERATURE CITED}

Abdul-Rashid MK, Riley JP, Fitzsimons MF, Wolff GA (1991) A simple method for the determination of volatile amines in sediment and water samples. Anal Chim Acta 252: $223-226$

Aller RC (1994) The sedimentary Mn cycle in Long Island Sound: its role as intermediate oxidant and the influence of bioturbation, $\mathrm{O}_{2}$ and $\mathrm{C}_{\text {org }}$ flux on diagenetic reaction balances. J Mar Res 52:259-295

Anthoni U, Christophersen C, Hougaard L, Neilsen PH (1991) Quaternary ammonium compounds in the biosphere-an example of a versatile adaptive strategy. Comp Biochem Physiol 99B:1-18

Bebianno MJ (1995) Effects of pollutants in the Ria Formosa lagoon. Sci Total Environ 171:107-115

Boulegue J, Lord CJ, Church TM (1992) Sulfur speciation and associated trace metals $(\mathrm{Fe}, \mathrm{Cu})$ in the pore waters of Great Marsh, Delaware. Geochim Cosmochim Acta 46: 453-464

Caetano M, Falcão M, Vale C, Bebianno MJ (1997) Tidal flushing of ammonium, iron and manganese from intertidal sediment pore waters. Mar Chem 58:203-211

Fitzsimons M, Jemmett AW, Wolff GA (1997) A preliminary study of the geochemistry of the methylamines in an estuarine salt marsh. Org Geochem 27:15-24

Fitzsimons M, Kamhi-Danon B, Dawit MD (2001) Distributions and adsorption of the methylamines in the inter-tidal sediments of an East Anglian estuary. Environ Exp Bot 46: 225-236

Franklin MJ, Wiebe WJ, Whitman WB (1988) Populations of methanogenic bacteria in a Georgia salt marsh. Appl Environ Microbiol 54:1151-1157

GEPP (1992) Aquaculture enquiry. Fishery recources, statistical series A-B (results from 1990-1991). Gabinete de Estudos e Planeamento das Pescas (GEPP), Ministério do Mar (Ministry of the Sea), Lisbon

Gibb SW, Mantoura RFC, Liss PS, Barlow RG (1999) Distributions and biogeochemistries of methylamines and ammonium in the Arabian Sea. Deep-Sea Res II 46:593-615

Harvey JW, Odum WE (1990) The influence of tidal marshes on upland groundwater discharge into estuaries. Biogeochemistry 10:217-236

Henrichs SM, Sugai SF (1993) Adsorption of amino acids and glucose by sediments of Resurrection Bay (Alaska): functional group effects. Geochim Cosmochim Acta 57: 823-835

Kerner M, Wallman K (1992) Remobilization events involving $\mathrm{Cd}$ and $\mathrm{Zn}$ from inter-tidal flat sediments in the Elbe estuary during the tidal cycle. Estuar Coast Shelf Sci 35: 371-393

Kim SG, Bae HS, Oh HM, Lee ST (2003) Isolation and characterisation of novel halotolerant and/or halophilic denitrifying bacteria with versatile metabolic pathways for the degradation of trimethylamine. FEMS Microbiol Lett 225: 263-269

King GM (1984) Metabolism of trimethylamine, choline and glycine betaine by sulphate reducing bacteria in marine sediments. Appl Environ Microbiol 48:719-725

Machás R, Santos R, Peterson B (2003) Tracing the flow of organic matter from primary producers to filter feeders in Ria Formosa lagoon, southern Portugal. Estuaries 26: 846-856

Marzo A, Curti S (1997) L-Carnitine moiety assay: an up-todate reappraisal covering the commonest methods for various applications. J Chromatogr 702:1-20

Morin J, Morse JM (1999) Ammonium release from resus- 
pended sediments in the Laguna Madre estuary. Mar Chem 65:97-110

Newton A, Icely JD, Falcao M, Nobre A, Nunes JP, Ferreira JG, Vale C (2003) Evaluation of eutrophication in the Ria Formosa coastal lagoon, Portugal. Cont Shelf Res 23: 1945-1961

Oremland RS, Marsh LM, Polcin S (1982) Methane production and simultaneous sulphate reduction in anoxic, salt marsh sediments. Nature 296:143-145

Raffaelli D, Hawkins S (1999) Intertidal ecology. Kluwer Academic Publishers, Dordrecht

Revsbech NP (1989) An oxygen microelectrode with a guard cathode. Limnol Oceanogr 34:474-478

Rocha C (1998) Rhythmic ammonium regeneration and flushing in inter-tidal sediments of the Sado estuary. Limnol Oceanogr 43:823-831

Rocha C, Cabral AP (1998) The influence of tidal action on porewater nitrate concentration and dynamics in intertidal sediments of the Sado estuary. Estuaries 21:635-645

Rocha C, Mesquita S, Vidal S, Galvão H (2001) Impact of Clam harvesting on benthic nitrifiers in sandy intertidal sediments of the Ria Formosa Coastal lagoon, Portugal. J Coastal Res SI 34 (ICS 2000 New Zealand):623-632

Seibel BA, Walsh PJ (2002) Trimethylamine oxide accumulation in marine animals: relationship to acylglycerol storage. J Exp Biol 205:297-236

Simon NS (1989) Nitrogen cycling between sediment and the shallow-water column in the transition zone of the Potomac river and estuary. II. The role of wind driven resuspension and adsorbed ammonium. Estuar Coast Shelf Sci 28:531-547

Smith RT (1975) Techniques in pedology: a handbook for environmental and resource studies. Elek, London

Editorial responsibility: Otto Kinne (Editor-in-Chief), Oldendorf/Luhe, Germany
Sobral P, Fernandes S (2004) Physiological responses and scope for growth of Ruditapes decussatus from Ria Formosa, southern Portugal, exposed to increased ambient ammonia. Sci Mar 68:219-225

Sobral P, Widdows J (1997) Influence of hypoxia and anoxia on the physiological responses of the clam Ruditapes decussatus from southern Portugal. Mar Biol 127: $455-461$

Sobral P, Widdows J (2000) Effects of increasing current velocity, turbidity and particle-size selection on the feeding activity and scope for growth of Ruditapes decussatus from Ria Formosa, southern Portugal. J Exp Mar Biol Ecol 245:111-125

Solomons TWG, Fryhle CB (2000) Organic chemistry, 7th edn. John Wiley \& Sons, New York

Sørensen J, Glob E (1987) Influence of benthic fauna on trimethylamine concentrations in coastal marine sediments. Mar Ecol Prog Ser 39:15-21

Sprung M (1994) Macrobenthic secondary production in the inter-tidal zone of the Ria Formosa - a lagoon in Southern Portugal. Estuar Coast Shelf Sci 38:539-558

Vila-Concejo A, Ferreira Ó, Matias A., Dias JMA (2003) The first two years of an inlet: sedimentary dynamics. Cont Shelf Res 23:1425-1445

Wang XC, Lee C (1990) The distribution and adsorption behaviour of aliphatic amines in marine and lacustrine sediments. Geochim Cosmochim Acta 54:2759-2774

Wang XC, Lee C (1994) Sources and distributions of aliphatic amines in salt marsh sediment. Org Geochem 22: 1005-1021

Wang XC, Lee C (1995) Decomposition of aliphatic amines and amino acids in anoxic salt marsh sediment. Geochim Cosmochim Acta 59:1787-1797

Submitted: December 9, 2003; Accepted: January 18, 2005 Proofs received from author(s): May 13, 2005 